\title{
Reconciling the Mountain Biodiversity Conservation and Human Wellbeing: Drivers of Biodiversity Loss and New Approaches in the Hindu- Kush Himalayas
}

\author{
NAKUL CHETTRI and EKLABYA SHARMA* \\ International Centre for Integrated Mountain Development (ICIMOD), GPO Box 3226, Kathmandu, \\ Nepal
}

(Received on 10 August 2015; Revised on 06 November 2015; Accepted on 17 December 2015)

\begin{abstract}
Mountains have long been admired and protected on the grounds of their wilderness,character and landscape beauty. But despite their remoteness and low human population density, many mountain ecosystems are strongly affected by drivers of global change. Mountain ecosystems in the tropical and sub-tropical regions have attracted the attention of a number of scientists, policy makers and natural resource managers because of their critical role in the supply of ecosystem services, and their vulnerability to environmental changes induced by anthropogenic and climatic factors. Adapting to and mitigating the effects of environmental change and sustaining ecosystem services in the context of a burgeoning human population is a major challenge. The Convention on Biological Diversity, Millennium Development Goals, and other international agreements explicitly connect conservation to poverty alleviation. It has become clear that nature conservation only works in practice if people's needs are also taken into account; while conservation efforts based on community participation and ownership tend to be more effective. A concerted effort is needed to develop a better scientific understanding of ecosystem structure and functioning and drivers of change as a basis for formulating comprehensive ecosystem management approaches and strategies that link to human wellbeing and poverty alleviation. This paper reviews the state of knowledge on five principle pressures, driving biodiversity loss in the $\mathrm{HKH}$ region, and describes evolving processes that highlight reconciliation of the conservation and development perspectives.
\end{abstract}

Keywords: Drivers of Change; Mountains; Ecosystem Approach; Trans-boundary Landscape

\section{Introduction}

Mountain ecosystems have long been admired and protected on the grounds of their serenity, wilderness character, and landscape beauty (Chester et al., 2013; Messerli and Ives, 1997). In general, direct human influence on the world's mountains is low, although there are marked differences between regions and mountain ranges. Only $6.5 \%$ of the world's mountain areas have a high level of direct human influence and more than half have only a low level (Huber et al., 2005). Not surprisingly, most heavily influenced mountain areas are located in the most densely populated regions in the world. Nevertheless, despite their remoteness and the low density of human population, many mountain ecosystems are strongly affected by drivers of global change such as land use change and climate change (Miehe et al., 2009; Shrestha et al., 2012) and are experiencing a loss of biodiversity. The mountain ecosystem in the Hindu Kush Himalayas (HKH) is no exception.

The HKH covers an area of more than four million square kilometres and includes all of Bhutan and Nepal and parts of Afghanistan, Bangladesh, China, India, Myanmar and Pakistan. It is one of the most diverse ecosystems among the global mountain biome with extreme variations in vegetation; climate and ecosystems resulted from altitudinal and latitudinal gradients (Sharma et al., 2010; Xu et al., 2009a). The region is the major source of ten major river systems (Table 1) and includes all or part of four

*Author for Correspondence: E-mail: eklabya.sharma@icimod.org 
Table 1: The ten major river basins with origins in the HKH region

\begin{tabular}{lllll}
\hline River basin & $\begin{array}{l}\text { Basin area } \\
\text { (per sq.km) }\end{array}$ & Countries & $\begin{array}{l}\text { Population } \\
\text { ('000) }\end{array}$ & $\begin{array}{l}\text { Population density } \\
\text { (per sq. km) }\end{array}$ \\
\hline Amu Darya & 534,739 & Afghanistan, Tajikistan, Turkmenistan, Uzbekistan & 20,855 & 39 \\
Brahmaputra & 651,335 & Bhutan, Bangladesh, China, India & 118,543 & 182 \\
Ganges & $1,016,124$ & Bangladesh, China, India, Nepal & 407,466 & 401 \\
Indus & $1,081,718$ & China, India, Pakistan & 178,483 & 165 \\
Irrawaddy & 413,710 & Myanmar & 32,683 & 79 \\
Mekong & 805,604 & Cambodia, China, Laos, Myanmar, Thailand, Vietnam & 57,198 & 71 \\
Salween & 271,914 & China, Myanmar, Thailand & 5,982 & 22 \\
Tarim & $1,152,448$ & China, Kyrgyzstan & 8,067 & 7 \\
Yangtze & $1,722,193$ & China & 368,549 & 214 \\
Yellow & 944,970 & China & 147,415 & 156 \\
Total & $\mathbf{8 , 5 9 4 , 7 5 5}$ & & $\mathbf{1 , 3 4 5 , 2 4 1}$ \\
\hline
\end{tabular}

Source: adapted from Eriksson et al., (2009)

Global Biodiversity Hotspots - Himalayan, IndoBurma, Mountains of South-West China and Mountains of Central Asia (Mittermeier et al., 2004) - which contain a rich variety of gene pools and species, ecosystems and endemic species of global importance (Table 2). The HKH is included in lists of 'Crisis Ecoregions', 'Biodiversity Hotspots', 'Endemic Bird Areas', 'Mega Diversity Countries', and 'Global 200 Ecoregions' (Brooks et al., 2006). The goods and services from the mountain ecosystem directly sustain 210 million people in the region and benefit some 1.3 billion people in the downstream river basin areas. The significance of HKH biodiversity as the source of a wide range of ecosystem goods and services has been well recognized by many scholars (Messerli and Ives, 1997; Viviroli et al., 2007). The HKH region plays an extremely important role as a provider of ecosystem goods and services to a downstream area with services such as provision of the vast water resources used for irrigation (Molden et al., 2014; Quyang, 2009), biodiversity based resources for food, shelter, and economic development (Pant et al., 2012; Sharma et al., 2015; Singh, 2002; 2006) and climate regulation (Messerli and Ives, 1997). However, although the region is rich in resources, the levels of poverty are generally higher than in the downstream counterpart areas (Gerlitz et al., 2012).

Environmental degradation has been identified as a major threat to the functioning of $\mathrm{HKH}$ ecosystems and flow of ecosystem services (Chettri et al., 2010; ICIMOD and RSPN 2014; ICIMOD and MoFSC 2014; Xu et al., 2009a). Globally, five principal pressures have been identified as directly driving biodiversity loss - habitat change, overexploitation, pollution, invasive alien species and climate change - and most are increasing rather than decreasing in intensity across the globe (MA, 2005; Secretariat of the CBD, 2014). Adapting to and mitigating the effects of these changes and sustaining ecosystem services in the context of a burgeoning human population is a major challenge in the $\mathrm{HKH}$ as

Table 2: Endemic species in the four Biodiversity Hotspots located in the HKH

\begin{tabular}{lllll}
\hline Hotspot & Mammals & Birds & Amphibians & Reptiles \\
\hline Himalaya & 24 & 128 & 75 & 128 \\
Indo-Burma & 165 & 312 & 216 & 333 \\
Mountains of Southwest China & 10 & 13 & 14 & 20 \\
Mountains of Central Asia & 6 & 0 & 4 & 1 \\
\hline
\end{tabular}

Source: Mittermeier et al., (2004) 
elsewhere (Molden et al., 2014; Xu J et al., 2009). It is important to improve scientific understanding of ecosystem structure and functioning and drivers of change as a basis for formulating comprehensive ecosystem management approaches and strategies that link to human well-being and poverty alleviation (Chettri et al., 2015; Molden et al., 2014). But, despite the significance of the HKH biodiversity, there has been little coordinated effort to understand the drivers of biodiversity loss or their impact on conservation and economic development (Sharma et al., 2010). The International Centre for Integrated Mountain Development has developed a programme on transboundary landscapes, which uses integrated and multidisciplinary research to increase scientific understanding of mountain ecosystems and to develop people-centred approaches to resource conservation that lead to sustainable and equitable development (see Chettri et al., 2009; Ning et al., 2014; Zomer and Oli, 2011). In this paper, we review the state of knowledge on five principle pressures driving biodiversity loss in the HKH region and describe evolving processes that highlight the reconciliation of the conservation and development perspectives.

\section{Drivers of Change and Impacts on Biodiversity}

The major driving forces identified as responsible for loss of biodiversity globally (habitat change, overexploitation, pollution, invasive alien species, and climate change) are all affecting biodiversity in the HKH region.

\section{Habitat Change}

The HKH is home to rich biodiversity including many charismatic species, such as Snow leopard (Uncia uncial), Red panda (Ailurus fulgens) among others (Kandel et al., 2015; Forrest et al., 2012). More than half (54\%) of the HKH area is rangeland (Fig. 1), a habitat for many species including Snow leopard (Uncia uncia) and trans-Himalayan ungulates (Chettri et al., 2012). This is followed by $26 \%$ agricultural land with rich agro-biodiversity (Partap and Sthapit 1998; Tulachand, 2001), and 14\% forest as habitat for a wide range of species, including Red

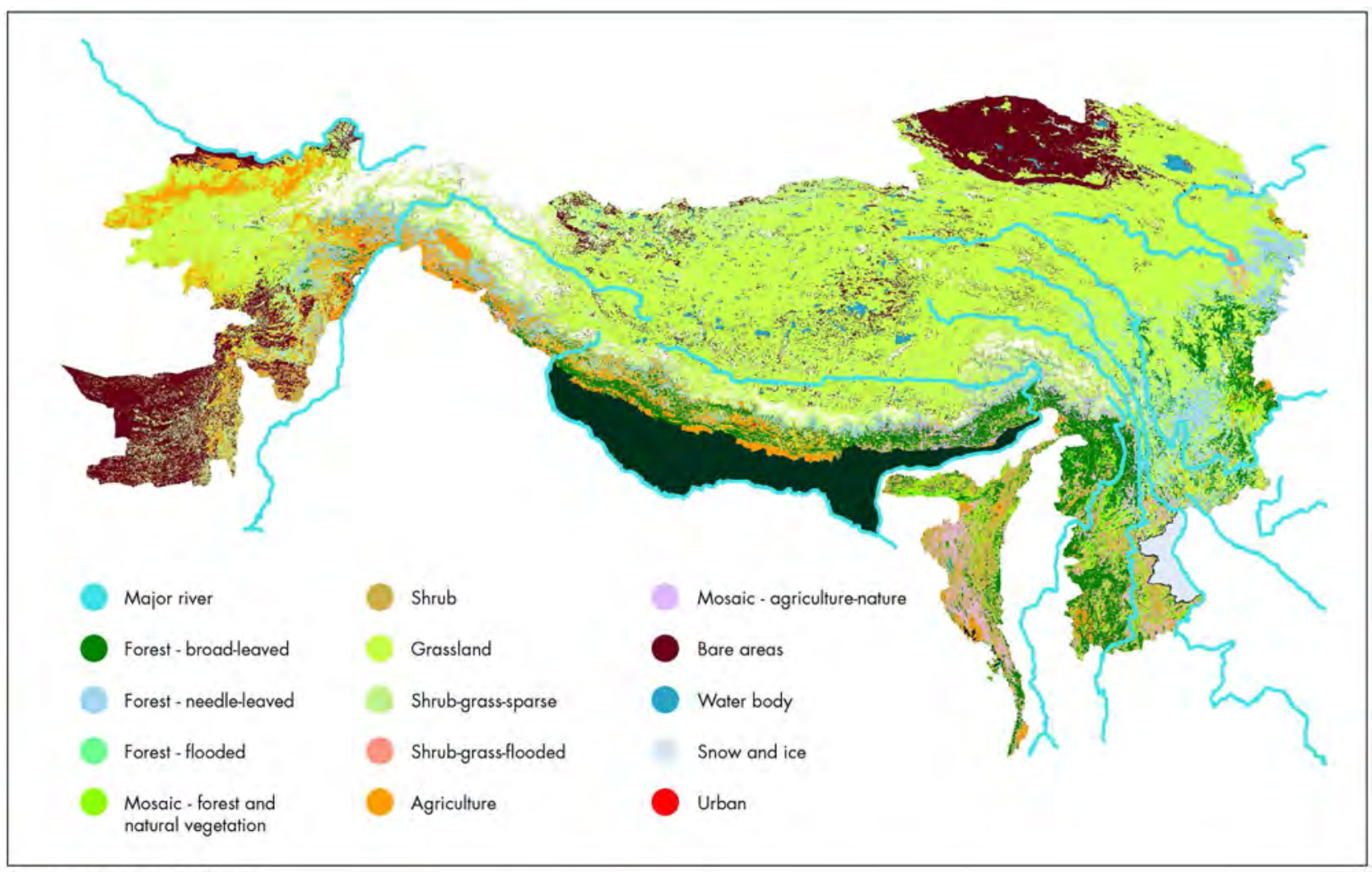

Source: Singh et al. (2011)

Fig. 1: Land use and land cover in the HKH region 
panda (Forrest et al., 2012; Kandel et al., 2015). Close to $40 \%$ of the land lies within some form of protected area (Table 3 ). Though there are variations in scale, change in land use and cover is prominent in many parts of the region (Cue and Graf, 2009; Gautam et al., 2004; Wakeel et al., 2005; Wang et al., 2008) with natural habitats shrinking through forest fragmentation (Pandit et al., 2007; Reddy et al., 2013; Uddin et al., 2015), regime shift (Brandt et al., 2013; Joshi et al., 2012), or changes in agriculture land (Semwal et al., 2004) and others. However, habitat degradation is not homogenous across the HKH. In some of the agro-ecological zones, the area used for agriculture is growing, with increases as high as 50\% reported in some watersheds in the Garhwal Himalayas between 1963 and 1993 (Sen et al., 2002). Annual loss of forest area of $0.2 \%$ has been reported for India (Reddy et al., 2013) and $0.3 \%$ for Myanmar (Leimgruber et al., 2005), although in Bhutan, forest cover is increasing at an annual rate of $0.22 \%$ (Gilani et al., 2015). Fragmentation and loss of forest, and conversion to agricultural land, means that for many species the available habitat is shrinking (Munsi et $a l ., 2010)$ and the connectivity required for species movement are fragmented (Zomer et al., 2001).

\section{Over-exploitation}

The area of our earth is finite, but the growth in world population and economic activity is leading to an increased demand for natural resources and ecosystem services (Lam, 2011). Recent remarkable economic growth in India and China brought many benefits through higher incomes and employment, but also fuelled threats to its ecosystems and biodiversity through habitat degradation and biodiversity loss (Squires, 2013). The anthropogenic pressure on natural resources are widely documented from across the HKH (Sundriyal and Sharma, 1996; Chettri et al., 2002; Bawa and Seidler 2015), many of the pressures are manifested to poverty (e.g. Bawa et al., 2007; Sandhu and Sandhu 2015) leading to over-exploitation (Adnam et al., 2015; Kala, 2015; Khan et al., 2012; Rikhari et al., 2000). The human pressure and overexploitation has been reported for valuable resources, such as Taxus baccata (Purohit et al., 2001; Poudel et al., 2013). These resources are widely used as they are simple to collect and freely available; other commercial sources are generally difficult to access as a result of high prices and limited supply (Chettri et al., 2002). Asia covers 14 per cent of the world, but contains half of the world's population, with population density eight times higher than the global average (MacKinnon, 2002). Humans annually

Table 3: Land cover and protected area in the HKH countries

\begin{tabular}{|c|c|c|c|c|c|c|c|c|}
\hline Country & $\begin{array}{l}\text { Total area } \\
\left(\mathrm{km}^{2}\right)\end{array}$ & $\begin{array}{l}\text { Total area w } \\
\text { HKH region } \\
\left(\mathrm{km}^{2}\right)\end{array}$ & $\begin{array}{l}\text { n the } \\
\% *\end{array}$ & $\begin{array}{l}\text { Population } \\
\text { in HKH area } \\
\text { in } 2007 \\
\text { (millions) }\end{array}$ & $\begin{array}{l}\text { Protected } \\
\text { area within } \\
\text { the HKH } \\
\left(\mathrm{km}^{2}\right)\end{array}$ & $\begin{array}{l}\text { Agricultural } \\
\text { area** within } \\
\mathrm{HKH}\left(\mathrm{km}^{2}\right)\end{array}$ & $\begin{array}{l}\text { Forested } \\
\text { area within } \\
\text { HKH }\left(\mathrm{km}^{2}\right)\end{array}$ & $\begin{array}{l}\text { Grassland, } \\
\text { shrubland } \\
\text { and other } \\
\left(\mathrm{km}^{2}\right)\end{array}$ \\
\hline Afghanistan & 641,903 & 391,560 & 61 & 28.48 & 2,461 & 94,577 & 2,179 & 235,935 \\
\hline Bangladesh & 137,878 & 15,543 & 11 & 1.33 & 632 & 2,723 & 4,920 & 7,912 \\
\hline Bhutan & 39,837 & 39,837 & 100 & 0.71 & 12,681 & 2,897 & 28,739 & 3,994 \\
\hline China & $9,369,194$ & $2,395,105$ & 26 & 29.48 & $1,522,172$ & 688,294 & 228,699 & $1,388,496$ \\
\hline India & $3,152,148$ & 404,701 & 13 & 72.36 & 62,417 & 99,886 & 140,097 & 137,806 \\
\hline Myanmar & 667,062 & 323,646 & 49 & 11.01 & 23,967 & 63,747 & 143,588 & 112,488 \\
\hline Nepal & 147,163 & 147,163 & 100 & 27.80 & 24,972 & 68,777 & 41,942 & 26,929 \\
\hline Pakistan & 876,534 & 479,039 & 55 & 39.36 & 18,721 & 84,644 & 5,541 & 354,044 \\
\hline Total & $15,031,719$ & $\sim 4,190,000$ & & 210.53 & $1,668,023$ & $1,105,546$ & 595,705 & $2,267,600$ \\
\hline $\begin{array}{l}\text { Proportion of } \\
\text { HKH total }\end{array}$ & & & & & $39 \%$ & $26 \%$ & $14 \%$ & $54 \%$ \\
\hline
\end{tabular}

*\% of total country area located in the HKH. **Agricultural area includes irrigated cropland, rain-fed cropland, mosaic cropland/ vegetation, and mosaic vegetation/cropland. Source: Bajracharya and Shrestha,(2011); Chettri et al. (2008) 
mobilize about 40 per cent of the total land primary production (Squires, 2014) and as a result, it exerts increasing pressure on these resources with often unsustainable levels of extraction accompanied by a marked loss in biodiversity (Bawa et al., 2007).

Recent studies have clearly revealed that the issues of poverty and population seem to "stand at one end of a long chain of cause and effect' and 'are the messenger of unsustainability rather than its agent' (UNFPA, 2001). There is a growing view that the poor are not necessarily the main agents responsible for resource degradation: quite often, the rich play a much greater role in this process (Jodha 2000). In some areas of the $\mathrm{HKH}$, there are evidences that the forested degradation is triggering due to commercial use and poor management practices (Ali and Benjaminsen, 2004) as reported for Taxus exploitation by Rikhari et al. (2000). But it is the poor who are the most vulnerable to the impacts of environmental degradation and biodiversity loss because of their higher dependency on these resources (Gerlitz et al., 2012; ICIMOD and RSPN, 2014). There are concerns about the intensive use of natural resources by local communities in the forests surrounding protected areas. But there are other more broader issues, such as internal domestic pressure (inequality, immigration, marginality, and cultural change), international pressure (macroeconomic policies, international trade factors), and policy responses (policy failure, poor environmental law, weak enforcement, unsustainable development projects, and lack of control over resources) that are seen as the underlying drivers of the over-exploitation of resources (Chettri et al., 2002; Jha and Bawa 2005; Mahat et al., 1987; Sundriyal and Sharma 1996).

\section{Pollution}

Pollution plays an important role in both ecosystem degradation and reduction in human well-being in the HKH (Geneletti and Dawa, 2009; Srivastava et al., 2014). However, despite the risks of pollution and the potential impacts on ecosystems and human health, it still receives little attention in the HKH region and has yet to become a priority topic. Direct levels of pollution reported in the HKH outside big cities are generally low, whether water, air, or noise (Sarkar 2010), but the number of studies is also limited. There is some documentation related to outdoor pollution with an impact on human health (e.g. Pandey et al., 1989; Sharma 2012), freshwater ecosystems (e.g. Korte et al., 2010) and others (Loewen et al., 2005; Shukla and Upreti 2008).

More recent studies have focused on pollution like black carbon, ozone, and mineral dust, which is transported to the region and in some cases is having a marked impact on the environment (Ramanathan and Carmichael 2008; Menon et al., 2010; Cristofanelli et al., 2014). Some studies have indicated, that the sources of the pollutants coming to the HKH lie as far as away as the Thar desert and Indo-Gangetic plains (Cong et al., 2015; Cristofanelli et al., 2014), and even across the Himalayas to reach the Tibetan plateau (Cong et al., 2015). The HKH is considered to be a hot-spot for impacts from the atmospheric brown cloud - with persistent high levels of shortlived climate forcers and pollutants such as ozone, black carbon, and other aerosol particles (see UNEP and GAW, 2011). Large amounts of absorbing particles such as black carbon and mineral dust can have multiple effects on biodiversity and ecosystems overall, as they accelerate local warming (Carrico et al., 2003; Gautam et al., 2010; Ménégoz et al., 2014). For example, scattering and absorption of solar radiation by the atmospheric brown cloud produces a solar dimming effect (Ramanathan et al., 2005). Excessive aerosol loading during the pre-monsoon season (especially during May) leads to reduced cloud cover and precipitation, which, in turn, heats the land surface, leading to strengthening of the monsoon in June and July (Bollasina et al., 2008). Higher proportions of black carbon and aerosol have implications for the regional and global climate, as well as, for hydrological regimes and the availability of freshwater over South Asia (e.g. Flanner et al., 2009; Qian et al., 2011; Xu B et al., 2009) that accelerate melting (ICIMOD 2011). Thus, the HKH can be strongly affected by vertical upward transport of air masses, that are rich in anthropogenic pollutants and mineral dust, especially during the pre-monsoon season (Bonasoni et al., 2010; Marinoni et al., 2010; 2013; Shrestha et al., 2010). The consequences are already reported by a number of scholars on biodiversity and ecosystems (Chettri et al., 2010; Hart et al., 2014; Shrestha et al., 2012) including, human health issues (Ebi et al., 2007; Sarkar 2010; Sharma 2012). 
Nakul Chettri and Eklabya Sharma

\section{Invasive Alien Species}

Over the past half century, the spread of alien invasive species has become a global challenge and the focus of intense management and research activities (Dogra et al., 2010; Kennedy et al., 2002). However, studies of invasive species in the HKH are sporadic, but cover a wide range of latitudes (Dobhal et al., 2011; Khuroo et al., 2007; Kosaka et al., 2010; Kunwar, 2003; Saxena and Ramakrishnan, 1984) and altitudinal gradients (Kosaka et al, 2010; Bhattarai et al., 2014). Both, Kosaka et al. (2010) and Bhattarai et al. (2014) reported that road construction facilitated plant invasion in mountainous regions of India and Nepal and the distribution pattern of invasive plants along roadsides varied with altitude. Bhattarai et al. (2014) found strong and positive correlation between invasive species and tree species diversity and negatively with elevation. There have been a number of inventories within the HKH (Towari et al., 2005; Dobhal et al., 2011; Khuroo, et al., 2012; Sekar, et al., 2012). In India, overall, the most recent inventory listed 1,599 species belonging to 842 genera in 161 families, $8.5 \%$ of the total Indian vascular flora (Khuroo, et al., 2012), while 190 invasive alien species belonging to 112 genera in 47 families were identified in the Indian Himalayas (Sekar, et al., 2012). Contrastingly, Khuroo et al. (2007) documentation reveals that the alien flora of Kashmir Himalaya alone is comprised of 571 plant species belonging to 352 genera and 104 families with Amaranthaceae and Chenopodiaceae include the highest percentage of 83 and 72 of alien species, respectively. In Nepal, 166 species were reported (Tiwari et al., 2005). Majority of the studies indicated that the origin of these species are America and Europe, and mostly herbaceous in nature. Some of the widely documented and spread species are Ageratum adenophora, Lantana camara, Parthenium adenophorus and Bidens pilosa. Eichornia crassipes are reported from marsh and swamp, whereas, Mikania micrantha from the forested areas. Interestingly, about $50 \%$ of the species are deliberately introduced in the Himalayas and others came through trade and gain imports (Sekar et al., 2012).

However, even though ecological studies have been quite substantial (Kohli, et al., 2006; Inderjit, et al., 2011; Bhatt, et al., 2011; Kohli, et al., 2012;
Tripathi, et al., 2012a; 2012b; Bajpai and Inderjit, 2013; Mandal and Joshi, 2015) and at different scales (Shah, et al. 2014), little effort has been made to study the impact on indigenous biodiversity, ecosystems, or human well-being (e.g. Kosaka, et al., 2010). There are various instances of evidence, including, reducing the plant diversity (Kohli, et al., 2004; Dogra, et al., 2009), habitat loss (Dobhal, et al., 2011) and loss of biodiversity (Bawa, et al., 2007; ICIMOD and MoFSC, 2014). However, comprehensive understating of the impacts of alien and invasive species to biodiversity in the $\mathrm{HKH}$ is far from complete.

\section{Climate Change}

The Inter-governmental Panel on Climate Change (IPCC) gave two pieces of information in its fourth assessment report (AR4) that drew global attention to the HKH region (IPCC, 2007). First, the report showed clearly the lack of data available to support assessments for the HKH region. Second, it made an erroneous claim that all glaciers in the Himalayas could disappear by 2035 (Cruz, et al., 2007), an error that was subsequently traced back to an inaccurate citation of the grey literature (Schiermeier, 2010). The controversy that ensued highlighted how little is known about the HKH region in general. However, notwithstanding the lack of detailed information, it is widely believed that the Hindu Kush-Himalayan region is one of the planet's hot-spots of climate change (see the ranking in Maplecroft, 2011).

There are relatively few climate stations in the $\mathrm{HKH}$ region and even fewer at high altitude, so that information on climate parameters over time is very limited. Table 4 summarizes the results of a few studies on changes in temperature and precipitation in different parts of the region. Despite the variation, the studies show a consistent warming trend over the past 100 years (see also Liu and Chen, 2000; Shrestha et al., 1999; Xu B et al., 2009; Yao et al., 2007). This indicates that the highland areas are susceptible to global climate change. A number of reports also indicate that the higher elevation areas have warmedup more than lowland areas; Liu and Chen (2000) argue that the Tibetan Plateau is a harbinger of climate change due to its early and accelerated warming. Based on various local and regional analyses, it is predicted that temperatures in the HKH will continue to rise in the future. For example, Rupa et al. (2006) 
Table 4: Changes in temperature and precipitation in different parts of the HKH region

\begin{tabular}{|c|c|c|c|c|}
\hline Area & Overall change of temperature & Precipitation & Period & Source \\
\hline Northeast Himalayas & $+1.0^{\circ} \mathrm{C}$ in winter, $+1.1^{\circ} \mathrm{C}$ in autumn & Small increase & $1901-2003$ & Dash et al., (2007) \\
\hline Southeast Himalayas & +0.008 to $+0.06^{\circ} \mathrm{C}$ per year & & $1960-1990$ & APN (2003) \\
\hline West China & +0.01 to $+0.04^{\circ} \mathrm{C}$ per year & $\begin{array}{l}-2.9 \text { to }-5.3 \mathrm{~mm} \text { per year } \\
\text { at one place }\end{array}$ & $1960-2000$ & $\begin{array}{l}\text { Yunling and Yiping, } \\
\text { (2005); Yin, (2006) }\end{array}$ \\
\hline Eastern Himalayas & $\begin{array}{l}\text { per year }<1,000 \text { masl }+0.01^{\circ} \mathrm{C} \text {; } \\
1,000<4,000 \text { masl }+0.02^{\circ} \mathrm{C} \text {; } \\
>4,000 \text { mas } 1+0.04^{\circ} \mathrm{C}\end{array}$ & & $1970-2000$ & $\begin{array}{l}\text { Shrestha and Devkota, } \\
\text { (2010) }\end{array}$ \\
\hline Bhutan & $\begin{array}{l}+0.5^{\circ} \mathrm{C} \text { (approx. } 0.03 \text { per year) } \\
\text { (non-monsoon period) }\end{array}$ & Uncertain & $1985-2002$ & T-sering (2003) \\
\hline
\end{tabular}

predict that temperatures on the Indian subcontinent will rise between 3.5 and $5.5^{\circ} \mathrm{C}$ by 2100 , while, Shi (2001) expects temperatures on the Tibetan Plateau to increase by $2.5^{\circ} \mathrm{C}$ by 2050 and $5^{\circ} \mathrm{C}$ by 2100 .

The historical trends in precipitation in $\mathrm{HKH}$ region are less clear, with varied and inconsistent results in different areas (Bhutiyani et al., 2010; Shrestha et al., 2000; Xu B et al., 2009). Ice core studies on the Tibetan Plateau indicate that both wet and dry periods have occurred since $960 \mathrm{AD}$ (Tan et al., 2007) and $1600 \mathrm{AD}$ (Yao et al., 2008). Further south, historical records show a weakening of monsoon in the 18th Century, followed by strengthening between the 19th Century and early 20th Century, and again weakening from the early 1920s to the present (Duan et al., 2004). During the past few decades, inter-seasonal, inter-annual and spatial variability in rainfall trends have been observed across Asia.

Observations of a cumulative negative mass balance of glaciers (Yao et al., 2007), increases in permafrost temperature (Zhao et al., 2004), and glacial recession (Seko et al., 1998; Fujita et al., 2001; Kadota et al., 2000) are also thought to reflect the impact of rising temperatures on the region (Table 5). In the last half century, $82 \%$ of the glaciers in western China have retreated (Liu et al., 2006), the glacial area on the Tibetan Plateau decreased by $4.5 \%$ over the last 20 years and $7 \%$ over the last 40 years $(\mathrm{CN}$ CCC, 2007). A recent modelling study on the Everest region of Nepal indicated that a large part of the glaciated area could sustain mass loss by the end of this century (Shea et al. 2015).
Continued de-glaciation as a result of climate change is expected to have a profound impact on the hydrological regimes of the ten rivers originating in the HKH (Akhtar et al., 2008; Barnett et al., 2005; Immerzeel et al., 2010; Shrestha and Aryal, 2011). River discharge is likely to increase for some time due to accelerated melting, but later as the glacier water storage capacity is reduced the flow is likely to decline (Eriksson et al., 2009; Nepal and Shrestha, 2015). A study by Lutz et al. (2014) also projected an increase in run-off to mid century caused by an increase in precipitation in the upper Ganges, Brahmaputra, Salween and Mekong basins and accelerated melt in the upper Indus Basin. The Indus, Tarim, Yangtze, Brahmaputra and Amu Darya are likely to experience the greatest loss in water availability later in the century due to loss of glacial melt (Xu B et al., 2009). Loss of glacier area and changes in water availability are likely to have an impact on the environmental resources in the region as well as people's well-being.

Changes in temperature and precipitation could have serious implications for biodiversity and the goods and services derived from it (Tse-ring et al., 2010; Singh et al., 2011). A wide range of community perception studies have also reported changing climate tends toward supporting the scientific observations (Chaudhary et al., 2011; Tse-ring et al., 2010; Vedwan, 2006). Observational evidence indicates that climate warming is already leading to visible effects in the HKH region with indications of changes in phenology (Hart et al., 2014; Ranjitkar et al., 2013) and degradation of vegetation (Arthur et al., 2007). There are also indications of changes in ecosystems 
Table 5: Changes in glacier area in the HKH region

\begin{tabular}{lll}
\hline Study area & Period & Overall change in glacier area $(\%)$ \\
\hline Su-Lo Mountain Glacier & $1966-1999$ & -7.0 \\
East Pamirs (northwestern Tibetan Plateau ) & $1962 / 66-1999$ & -7.9 \\
Xinqingfeng (northwestern Tibetan Plateau) & $1973-2000$ & -1.7 \\
Geladandong (central Tibetan Plateau) & $1969-2002$ & -4.8 \\
Karakoram (northwestern Tibetan Plateau) & $1969-1999$ & -4.1 \\
Pumqu (central Himalayas) & $1970-2001$ & -9.0 \\
Naimona'nyi (western Himalayas) & $1976-2003$ & -8.8 \\
Daxue Mountain (northeastern Tibetan Plateau) & $1956-1990$ & -4.8 \\
A'nyêmaqên Mountain (northeastern Tibetan Plateau) & $1966-2000$ & -17.0 \\
West Kunlun (northwestern Tibetan Plateau ) & $1970-2001$ & -0.4 \\
Zemestan Glacier, Wakhan corridor & $1976-2003$ & -10.0 \\
Rongbuk Glacier, Everest, Nepal & $1966-1997$ & recession by 170-270 m \\
\hline
\end{tabular}

Source: Dahe et al., (2000); Wang et al., (2008)

(Shrestha et al., 2012); some ecoregions are likely to be more vulnerable to climate change than others (Chettri et al., 2010; Tse-ring et al. 2010) as climate change may shift the existing climatic zones (Zomer et al., 2014); change the available habitats of iconic species such as Snow leopard (Forrest et al., 2012) and the availability of highly valuable Chinese caterpillar-plant (Cordyceps sp.) (Shrestha and Bawa, 2014) among other. Observation has also been made on reduction on agriculture production in some of the major crops in some parts of the HKH (Aggrawal, 2008; Vedan et al., 2001).

\section{The Changing Paradigm}

Biodiversity conservation has made a great progress using the protected area approach at national (Deguignet et al., 2014), regional (Chettri et al., 2008; Clark et al., 2013), and global levels (Deguignet et al., 2014; Watson et al., 2014). The approach has become more successful with the increasing recognition of the role of biodiversity and ecosystemderived goods and services in addressing economic development and poverty alleviation (Motel et al., 2014; Ros-Tonen et al., 2005; Zedan, 2005), and of the need to involve local communities in a holistic conservation effort, rather than exclude them from designated areas (Sharma et al., 2010). The need for conservation and development through poverty alleviation are now well recognised in global policy frameworks - the Convention on Biological Diversity and the Millennium Development Goals (now has become the Sustainable Development Goals) (Zedan, 2005; Giggs, 2013).

In recent decades, the HKH has also witnessed significant conceptual development in regional approaches to biodiversity conservation, from 'people exclusionary' and 'species focused' to 'people-centred community-based' and 'ecosystem/landscape approach', as reflected by conservation policies and practices within the various countries in the region (Sharma et al., 2010). The classical approach of biodiversity conservation, which started with an emphasis on the conservation of flagship species (e.g. Yonzon, 1989; Wikramanayake et al., 1998) evolved to the understanding that "conservation and management of biodiversity are impossible without people's participation" (Chettri and Shakya, 2008). Since 1980s, de-centralization and devolution of authority for biodiversity conservation were evident in Governments' efforts across the HKH region (see Sharma et al., 2010). The United Nations Conference on Environment and Development (UNCED) in 1992 placed a premium on people's participation and promotion of this conceptual shift in both natural resources management and biodiversity conservation. In response, participatory forest management approaches evolved as accepted means in the HKH (Sharma and Chettri, 2003). During the process, it 
was realised that biodiversity management by local people is more effective when the utility value and benefit to communities thereof is evident. For example, successful examples of community-based biodiversity conservation linked to enterprise development include oak-based silk production in Garhwal (India); Jatamansi (Nardostachys jatamansi) in Humla (Nepal); traditional local paper from lokta (Daphne spp.) and argeli (Edgeworthia gardeneri) in Nepal; and ecotourism in India (Sikkim) and Nepal (Annapurna Conservation Area) (see Sharma et al., 2006). In all of these examples, and many others, community-based biodiversity conservation was seen as instruments that enhance conservation and sustainable use of threatened or vulnerable species and or ecosystems.

In addition, the conservation approaches in the HKH took on a new dimension with the concept of linking the existing protected areas with corridors (Sherpa and Norbu, 1999). This approach, while addressing the biophysical advantages of corridors for migration, habitat contiguity, species refugia for restoration, and shifting of species and habitat types in response to environmental pressures such as climate change, also incorporates the notion that communities and how they manage their natural resources play an important role both in connecting protected areas, and the effectiveness of those protected areas. Subsequently, the concept of landscape-level conservation approaches (Smith and Maltby, 2003; Secretariat of the CBD, 2004) evolved in the region generally adopting the 'Ecosystem Approach' advocated by the CBD (see Sherpa et al., 2003; Sherpa et al., 2004; GoN/MFSC, 2006; Chettri et al., 2007; Zomer and Oli, 2011).

\section{Reconciling Conservation and Human Wellbeing using the Landscape Approach}

Landscape-level biodiversity conservation is an evolving concept in the HKH (Sherpa and Norbu, 1999; Sharma and Chettri 2005; Chettri et al., 2007; Zomer and Oli, 2011). The concept has emerged primarily out of recognition that strict protection through a network of protected areas (e.g. national parks, sanctuaries, wildlife reserves) is an essential but insufficient strategy for biodiversity conservation (Chettri et al., 2007; Chettri et al., 2009). Now, the focus has shifted from simply preserving isolated patches of sustained wilderness in the form of protected areas, to the need for maintaining landscape integrity and to see - and conserve - ecosystems as part of larger agro-ecological and socio-cultural landscapes (Chettri et al., 2015). However, the progress towards wider landscape approach is also witnessing various challenges including the human wildlife conflict (HWC). The increasing conservation efforts including protection through policy and practices have resulted in increase in population of many wildlife species (Selvan et al., 2014; Ashraf et al., 2015; Raza et al 2015). As a result, the HWC has also increased substantially across the $\mathrm{HKH}$,adding more challenges in conservation (Carter et al., 2012; Kabir et al., 2014; Sapkota et al., 2014).

The trans-boundary landscape approach is gaining prominence in many areas in the search for solutions to reconcile these conservation and development tradeoffs (see Sharma et al., 2007; Zomer and Oli, 2011).

There are a number of landscape level initiatives for biodiversity conservation in $\mathrm{HKH}$ at different development levels (Table 6). The majority of these initiatives have looked at ways of reconciling conservation with development with a focus on community well-being. In recent years, the International Centre for Integrated Development (ICIMOD) has been advocating for bio-diversity conservation and sustainable development in the HKH region using an ecosystem approach within transboundary landscapes, and including consideration of cross-cutting issues related to policy, governance, and equity and gender, while mainstreaming principles of information and knowledge management. The concept is to bring $\mathrm{HKH}$ regional member countries together to facilitate effective conservation in critical transboundary complexes. Six potential landscape areas have been identified (Fig. 2) and a four-step framework (Fig. 3) is being used to support programme design. The programme has a strong element of monitoring change through long-term environmental and socio-ecological monitoring (see Chettri et al., 2015) and focuses on managing the landscapes to sustain the flow of ecosystem goods and services in order to improve livelihoods and enhance ecological integrity, economic development, and socio-cultural resilience to environmental changes (Box 1). There are five thematic focus areas: 
Table 6: Landscape initiatives in the HKH region

\begin{tabular}{|c|c|c|c|}
\hline Landscape initiative & Geographical area & Main themes & Source \\
\hline $\begin{array}{l}\text { Bhutan Biological } \\
\text { Conservation Complex }\end{array}$ & Bhutan & $\begin{array}{l}\text { Community-based conservation in protected } \\
\text { areas and conservation corridors }\end{array}$ & $\begin{array}{l}\text { Sherpa and Norbu (1999); } \\
\text { NCD (2004) }\end{array}$ \\
\hline Everest Complex & China and Nepal & $\begin{array}{l}\text { Regional cooperation, information sharing, } \\
\text { and developing decision making tools }\end{array}$ & $\begin{array}{l}\text { Sherpa et al. }(2003) \\
\text { Bajracharya et al. }(2010)\end{array}$ \\
\hline Terai Arc Landscape & Nepal & $\begin{array}{l}\text { Community-based conservation in protected } \\
\text { areas and conservation corridors }\end{array}$ & Gurung (2004) \\
\hline Kangchenjunga Landscape & $\begin{array}{l}\text { Eastern Nepal, Sikkim } \\
\text { and north Bengal in India, } \\
\text { and western Bhutan }\end{array}$ & $\begin{array}{l}\text { Conservation and development in protected } \\
\text { areas and conservation corridors }\end{array}$ & Sharma and Chettri (2005) \\
\hline Kailash Sacred Landscape & $\begin{array}{l}\text { Western Nepal, Uttara- } \\
\text { khand in India and Tibet } \\
\text { Autonomous Region in } \\
\text { China }\end{array}$ & $\begin{array}{l}\text { Conservation and development around sacred } \\
\text { sites and in protected areas }\end{array}$ & Zomer and Oli (2011) \\
\hline Far-Eastern Himalayas & $\begin{array}{l}\text { Arunachal Pradesh in India, } \\
\text { Kachin State in Myanmar } \\
\text { and Yunnan in China }\end{array}$ & $\begin{array}{l}\text { Conservation and development in biodiversity } \\
\text { hotspots }\end{array}$ & $\begin{array}{l}\text { Guangwei (2002); } \\
\text { Shakya et al. (2011) }\end{array}$ \\
\hline $\begin{array}{l}\text { Karakoram Pamir and } \\
\text { Wakhan }\end{array}$ & $\begin{array}{l}\text { Afghanistan, China, } \\
\text { Pakistan, and Tajikistan }\end{array}$ & $\begin{array}{l}\text { Conservation and development in arid } \\
\text { ecosystems }\end{array}$ & Ning et al. (2014) \\
\hline
\end{tabular}

Box 1. Programme on Conservation and Sustainable Use of Transboundary Landscapes

Goal: Trans-boundary landscapes are better conserved and managed for sustaining ecosystem goods and services, and to improve livelihoods and enhance ecological integrity, economic development, and socio-cultural resilience to environmental changes.

Overall objectives: Improved cooperation among regional member countries of the Hindu Kush Himalayas for sustainable and inclusive ecosystem management in identified landscapes for enhanced and equitable livelihood benefits, climate change resilience, and contributing to global conservation agendas.

The specific objectives (five major domains of change) for the programme are:

1) Improve livelihoods and climate change adaptation of mountain communities

2) Enhance community-based participatory ecosystem management

3) Improve resource governance

4) Strengthen long-term environmental and socioeconomic monitoring systems

5) Establish regional cooperation, knowledge management and an enabling policy environment.

livelihoods and climate change adaptation (socioeconomic development), community-based participatory ecosystem management (ecosystem wellbeing), resources governance, long-term monitoring, and regional cooperation (Fig. 4). The priority areas are addressed using a consultative process keeping socio-economic development as the central focus.

The programme is now working in four 


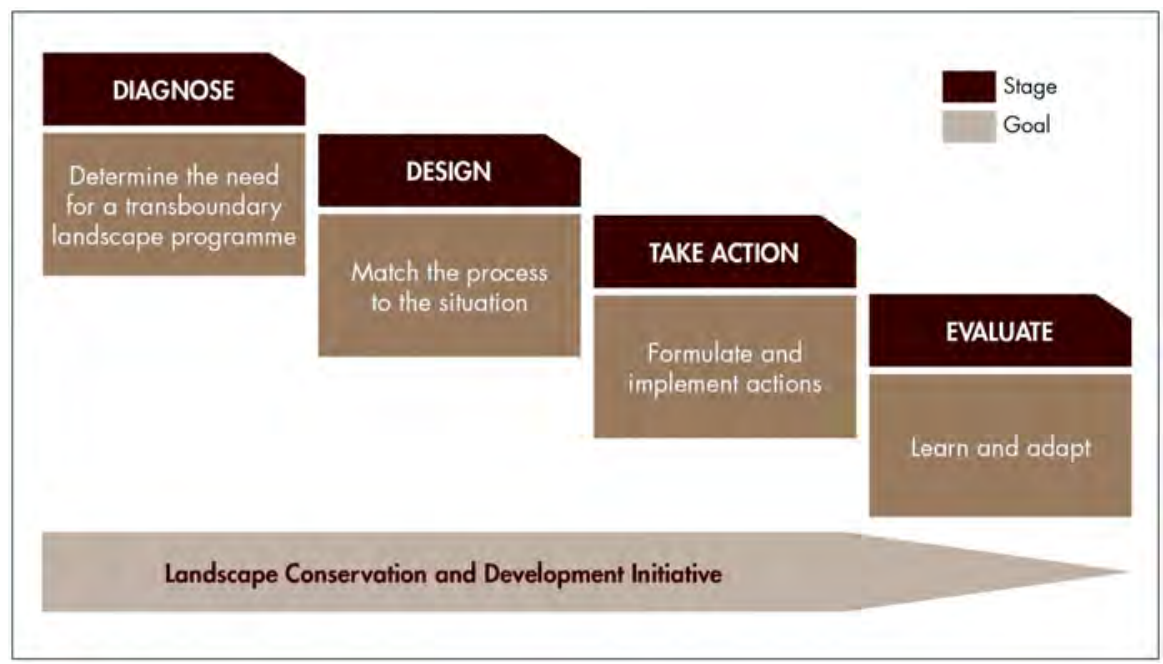

Fig. 2: Four common stages in trans-boundary landscape programmes (sources - Adapted with modification from Erg et al., (2012)

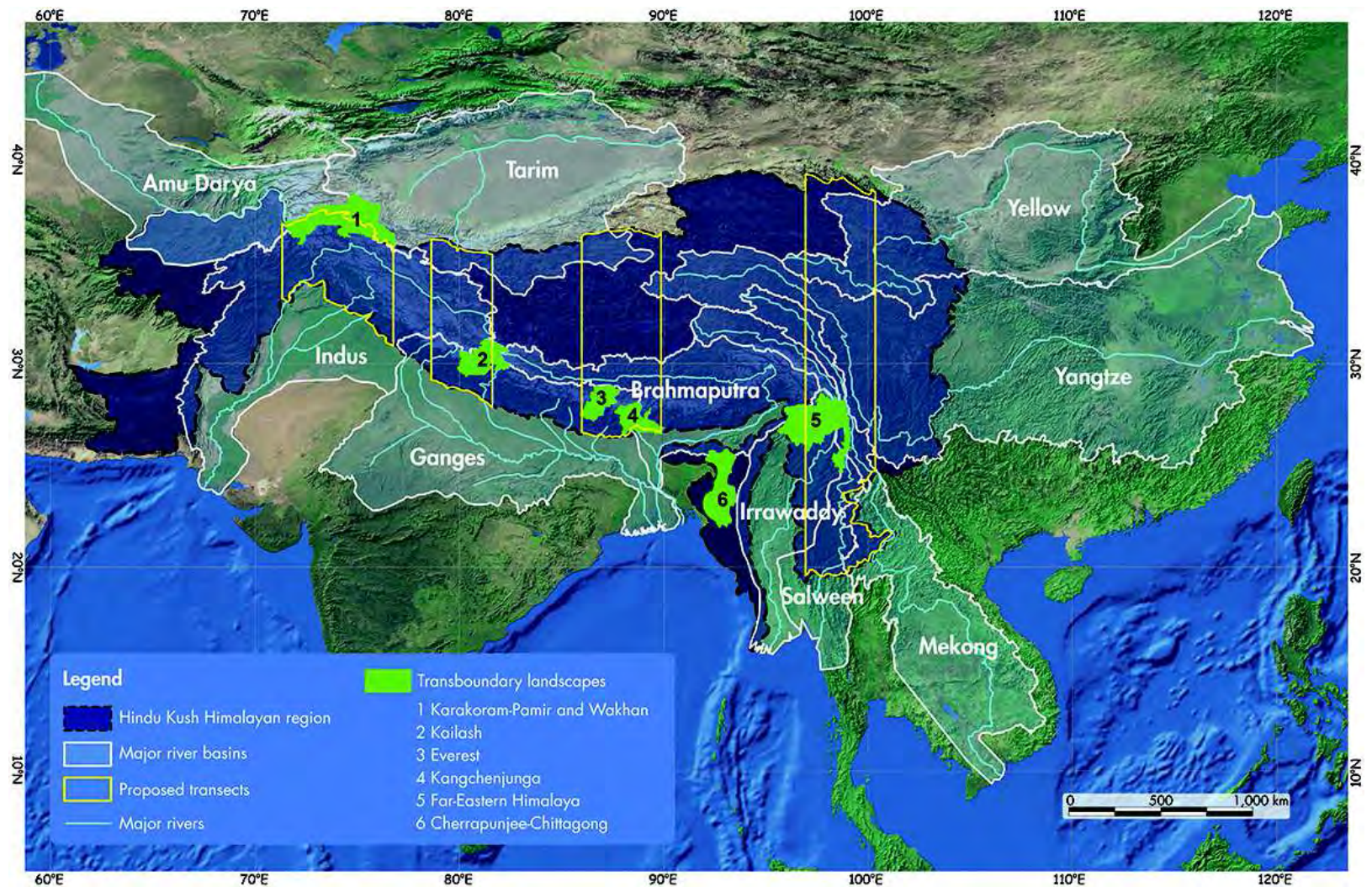

Fig. 3: The six selected trans-boundary landscapes in the HKH region

landscapes, with three at the initial stages of diagnosis and design (Karakoram Pamir and Wakhan, Kangchenjunga and Far Eastern Himalayas) and one in the early stages of implementation (Kailash) (Chettri et al., 2007; Ning et al., 2014; Sharma and
Chettri, 2005; Zomer and Oli, 2011). All of these programmes have a long term vision of 20 years and the strategic process of conservation and development interventions have been developed. The participating countries have also shown ownership of the 


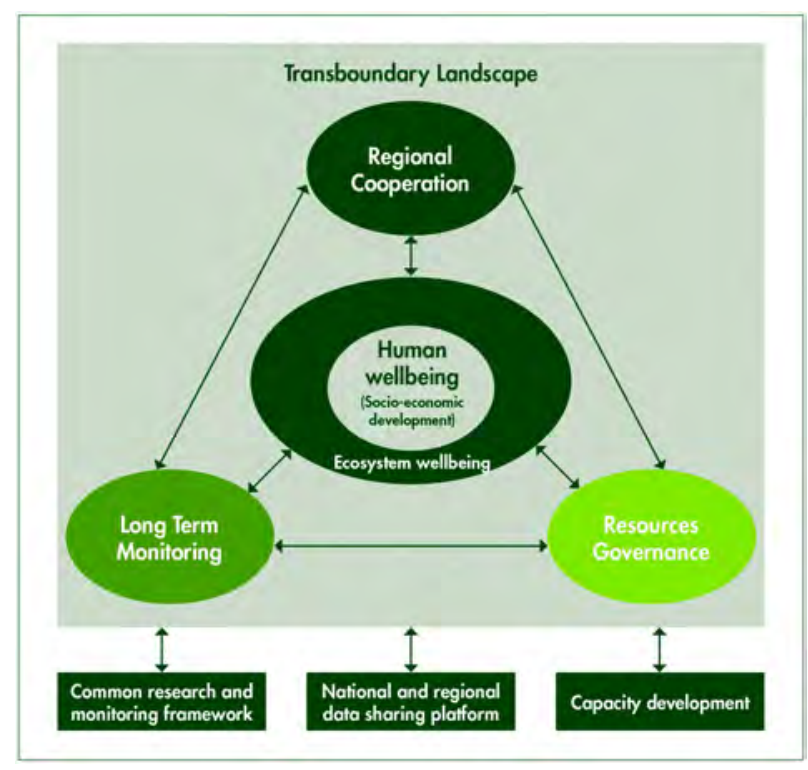

Fig. 4: Schematic flowchart of the five thematic focus areas in the trans-boundary landscapes programme and the linkages between them

programme and are making commitments to work at the landscape level in the trans-boundary areas. Efforts are also being made to look at major threats identified at the global scale. Some work has been initiated on habitat change through land use cover change and forest fragmentation (Uddin et al., 2015), overexploitation (Chettri et al., 2002), climate change (Zomer et al., 2014), and pollution and invasive alien species.

\section{Conclusion}

Global biodiversity is under acute pressure from the anthropogeic pressure and destruction of habitats. This is manifested in local, national and international pressure as well as policy responses. Drivers of change include forest degradation and habitat fragmentation as a result of agricultural intensification, overexploitation of resources, and industrial and economic development. Pollution is affecting both ecosystems and human health, and habitats are being changed by invasive and alien species, making conservation and development a more challenging task than ever. Climate variability and change are adding to the burden of these challenges. The international community is realizing the urgent need for holistic development integrating multidisciplinary approaches, a strong research base, and participatory decision making to address the challenges at a regional and transboundary scale.

Protected areas have increased greatly in number and extent but cannot exist in isolation as islands, neither within countries nor across national borders, as they are embedded in a matrix of human needs and surrounding lands. They are also insufficient to achieve local, national, regional, and global conservation goals. Experience has shown that biodiversity conservation requires a comprehensive and multi-scaled approach, that includes both reserve and non-reserve areas and takes into account people's dependence on resources for their subsistence. A holistic approach is needed at the landscape/ ecosystem scale which includes people as part of the system. The integrated approach to conservation is supported by efforts to reconcile conservation with development by ensuring that communities both participate in and benefit from conservation approaches.

Over the past decade, ICIMOD has been playing a pivotal role in the $\mathrm{HKH}$ in forming partnerships, developing community-based natural resource management strategies in and around protected areas, and exploring the feasibility of developing transboundary landscapes. Recent trans-boundary initiatives promote participatory processes and landscape level ecosystem management to address trans-boundary conservation and sustainable development. They provide a unique opportunity for long term visions and strategies to promote regional cooperation and common understanding on transboundary landscape issues, including the impact of climate change, to conserve this irreplaceable cultural and natural landscape. The initiatives support the aim of the HKH countries to sustainably manage the cultural and ecological diversity in the region as well as the broad objectives of global efforts, as reflected in the CBD and other relevant international conventions. A strong thrust has been given to community development at the local level, as well as. to cooperation at the regional level to meet global commitments.

\section{Acknowledgements}

The authors would like to express their gratitude to Dr David Molden, Director General of ICIMOD, for 
his inspiration and support. The continuous support and commitment from ICIMOD's eight regional member countries is also acknowledged, as is the support of Austrian Development Agency (ADA), German Federal Ministry for Economic Cooperation and Development (BMZ) through its German Agency

\section{References}

Adnan M, Tariq A and Shinwari Z K (2015) Effects of human proximity and nomadic grazing on the diversity of medicinal plants in temperate Hindukush Pak J Bot $\mathbf{4 7}$ 149-157

Aggarwal P K (2008) Global climate change and Indian agriculture: impacts, adaptation and mitigation Indian J Agr Sci 78 911-919

Akhtar M, Ahmad N and Booij M J (2008) The impact of climate change on the water resources of Hindukush-KarakorumHimalaya region under different glacier coverage scenarios $J$ Hydrol 355 148-163

Andam K S, Ferraro P J, Sims K R E, Healy A and Holland M B (2010) Protected areas reduced poverty in Costa Rica and Thailand Proc Natl Acad Sci USA 107 9996-10001

APN (2003) Global change impact assessment for Himalayan mountain regions: Resource management and sustainable development. Final Report. Kathmandu: APM www.apn.gr.jp/en/products/project_report/2003/ finalreport/2003-03.pdf (accessed 15 September 2011)

Ali J and Benjaminsen T A (2004) Fuelwood, timber and deforestation in the Himalayas: the case of Basho Valley, Baltistan region, Pakistan Mt Res Dev 24 312-318

Arthur AD, Pech R P and Jiebu (2007) Grassland degradation on the Tibetan Plateau: The role of small mammals and methods of control. Australian Centre for International Agricultural ResearchTechnical Reports No. 67, Australian Centre for International Agricultural Research, Canberra, Australia

Ashraf N, Anwar M, Hussain I and Mirza S N (2015) Population parameters of Grey goral (Naemorhedus goral goral) at two different sites in Machiara National Park, Azad Jammu and Kashmir, Pakistan J Anim Plant Sci 25 88-94

Bajpai D and Inderjit (2013) Impact of nitrogen availability and soil communities on biomass accumulation of an invasive species AoB Plants 5 plt045. doi:10.1093/aobpla/plt045

Bajracharya B, Pradhan S, Shrestha B and Salerno F (2010) An integrated Decision Support Toolbox (DST) for the for International Cooperation (GIZ), and the Department of International Development (DFID), United Kingdom, which made this publication possible. Our sincere thanks go to Dr. A Beatrice Murray for language editing of the manuscript.

management of mountain protected areas Mt Res Dev $\mathbf{3 0}$ 94-102

Bajracharya S R and Shrestha B (2011) The status of glaciers in the Hindu Kush-Himalayan region. ICIMOD, Kathmandu, Nepal

Barnett T P, Adam J C and Lettenmaier D P (2005) Potential impacts of a warming climate on water availability in snowdominated regions Nature 438 303-309

Bawa K S and Seidler R (2015) Deforestation and sustainable mixed-use landscapes: A view from the Eastern Himalaya An Mo Bot Gard 100 141-149

Bawa K S, Joseph G and Setty S (2007) Poverty, biodiversity and institutions in forest-agriculture ecotones in the Western Ghats and Eastern Himalaya ranges of India Agric Ecosyst Environ 121 287-295

Bhatt J R, Singh J S, Singh S P, Tripathi R S and Kohli R K (2011) Invasive Alien Plants - An Ecological Appraisal for the Indian Subcontinent (Vol. 1). CAB International Publishing: Wallingford, Oxon, UK

Bhattarai K R, Måren I E and Subedi S C (2014) Biodiversity and invasibility: Distribution patterns of invasive plant species in the Himalayas, Nepal J Mt Sci 11 688-696

Bhutiyani M R, Kale V S and Pawar N J (2010) Climate change and the precipitation variations in the north-western Himalaya: 1866-2006 Int J Climatol 30 535-548

Bollasina M, Nigam S and Lau K M (2008) Absorbing aerosols and summer monsoon evolution over South Asia: An observational portrayal J Climate 21 3221-3239

Bonasoni P, Laj P, Marinoni A, Sprenger M, Angelini F, Arduini J, Bonafe' U, Calzolari F, Colombo T, Decesari S, Biagio C D, Sarra A G di , Evangelisti F, Duchi R, Facchini M C, Fuzzi S, Gobbi G P, Maione M, Panday A, Roccato F, Sellegri K, Venzac H, Verza G P, Villani P, Vuillermoz E and Cristofanelli P (2010) Atmospheric Brown Clouds in the Himalayas: first two years of continuous observations at the Nepal climate observatory-pyramid (5079 m) Atmos Chem Phys 10 7515-7531

Brandt J S, Haynes M A, Kuemmerle T, Waller D M and Radeloff 
V C (2013) Regime shift on the roof of the world: Alpine meadows converting to shrublands in the southern Himalayas Biol Conserv 158 116-127

Brooks T M, Mittermeier R A, da Fonseca G A B, Gerlach J, Hoffmann M, Lamoreux J F, Mittermeier C G, Pilgrim J D and Rodrigues A S L (2006) Global biodiversity conservation priorities Science 313 58-61

Brussaard L, P Caron, B Campbell, L Lipper, S Mainka, R Rabbinge, D Babin and M Pulleman 2010. Reconciling biodiversity conservation and food security: scientific challenges for a new agriculture Curr Opin Environ Sustain 2 34-42

Carrico C M, Bergin M H, Shrestha A B, Dibb J E, Gomes L and Harris J M (2003) The importance of carbon and mineral dust to seasonal aerosol properties in the Nepal Himalaya Atmos Environ 37 2811-2824

Carter N H, Shrestha B K, Karki J B, Pradhan N M B and Liu J (2012) Coexistence between wildlife and humans at fine spatial scales Proc Natl Acad Sci U S A 109 15360-15365

Chaudhary P, Rai S, Wangdi S, Mao A, Rehman N, Chettri S and Bawa K S (2011) Consistency of local perceptions of climate change in the Kangchenjunga Himalaya landscape Curr Sci 101 504-513

Chester C C, Hilty J A and Hamilton L S (2013) Mountain gloom and mountain glory revisited: A survey of conservation, connectivity, and climate change in mountain regions $J M t$ Ecol 9 1-34

Chettri N, Bubb P, Kotru R, Rawat G S Ghate R, Murthy M S R, Wallrapp C, Pauli H, Shrestha A B, Mool P K, Chaudhary D, Chaudhary R P, Mathur P K, Peili S, Ning W and Sharma E (2015) Long-Term Environmental and Socioecological Monitoring in Transboundary Landscapes: An Interdisciplinary Implementation Framework. ICIMOD Working Paper 2015/2. Kathmandu: ICIMOD

Chettri N, Shakya B, Thapa R and Sharma E (2008) Status of protected area system in the Hindu Kush Himalaya: an analysis of PA coverage Int J Biodiver Sci Manag 4 164178

Chettri N, Sharma E, Deb D C and Sundriyal R C (2002) Effect of firewood extraction on tree structure, regeneration, and woody biomass productivity in a trekking corridor of the Sikkim Himalaya Mt Res Dev 22 150-158

Chettri N, Sharma E, Shakya B and Bajracharya B (2007) Developing forested conservation corridors in the Kangchenjunga Landscape, Eastern Himalaya Mt Res Dev 27 211-214

Chettri N, Sharma E, Shakya B, Thapa R, Bajracharya B, Uddin
K, Oli K P and Choudhury D (2010) Biodiversity in the Eastern Himalayas: Status, trends and vulnerability to climate change; Climate change impact and vulnerability in the Eastern Himalayas - Technical report 2. Kathmandu: ICIMOD

Chettri N, Sharma E and Thapa R (2009) Long-term monitoring using transect and landscape approaches within the Hindu Kush-Himalayas. In International Mountain Biodiversity Conference (Ed: Sharma E) pp 201-208, ICIMOD, Kathmandu, Nepal

Chettri N and B Shakya (2008) Species to landscape: A paradigm shift in biodiversity conservation through people's participation and policy reform. In: Policy Priorities for Sustainable Mountain Development: Proceedings and Selected Papers from the Regional Policy Workshop', September 18-20, 2006 (Eds: Rasul G and Karki M) Kathmandu, ICIMOD, Nepal. CD Rom.

Chettri N, Sharma E, Shrestha AB, Zhoali Y, Hua Q and B Bajracharya (2012) Real world Protection for the Third Pole and its people. In: Protection of Polar Regions (Ed. Huettmann F) pp 113-133, Springer, Japan

Clark N E, Boakes E H, McGowan P J K, Mace G M and Fuller R A (2013) Protected areas in south asia have not prevented habitat loss: A study using historical models of land-use change PLoS One 8 e65298. doi:10.1371/journal. pone.0065298

CNCCC (2007) China national report on climate change 2007 (in Chinese). Beijing: China National Committee on Climate Change

Cong Z, Kawamura K, Kang S and Fu P (2015) Penetration of biomass-burning emissions from South Asia through the Himalayas: new insights from atmospheric organic acids $\mathrm{Sci}$ Rep 5 9580 | DOI: 10.1038/srep09580

Cristofanelli P, Putero D, Adhikary B, Landi T C, Marinoni A, Duchi R, Calzolari F, Laj P, Stocchi P, Verza G, Vuillermoz E, Kang S, Ming J and P Bonasoni (2014) Transport of short-lived climate forcers/pollutants $(\mathrm{SLCF} / \mathrm{P})$ to the Himalayas during the South Asian summer monsoon onset Environ Res Letters doi:10.1088/1748-9326/9/8/084005

Cruz R V, Harasawa H, Lal M and Wu S (2007) 'Asia.' In Climate change 2007: Impacts, adaptation, and vulnerability. Contribution of Working Group II to the Fourth Assessment Report of the Intergovernmental Panel on Climate Change, (Eds. Parry M L, Canziani O F, Palutikof J P, Van Der Linden P J and Hanson C E) pp 470-506 Cambridge, UK: Cambridge University Press

Cui X and Graf H F (2009) Recent land cover changes on the 
Tibetan Plateau: a review Clim Chang 94 47-61

Dahe Q, Mayewski PA, Wake C P, Shichang K, Jiawen R, Shugui H, Tandong Y, Yang Q, J Zhefan and Mi D (2000) Evidence for recent climate change from ice cores in the central Himalaya Ann Glaciol 31 153-158

Dash S K, Jenamani R K, Kalsi S R and Panda S K (2007) Some evidence of climate change in the twentieth-century India. Clim Chang 85 299-321

Deguignet M, Juffe-Bignoli D, Harrison J, MacSharry B, Burgess $\mathrm{N}$ and Kingston N (2014) United Nations list of protected areas. UNEP-WCMC, Cambridge, UK

Dobhal P K, Kohli R K and Batish D R (2011) Impact of Lantana camara L. invasion on riparian vegetation of Nayar region in Garhwal Himalayas (Uttarakhand, India) $J$ Ecol Nat Environ 3 11-22

Dogra K S, Kohli R K and Sood S K (2009) An assessment and impact of three invasive species in the Shivalik hills of Himachal Pradesh, India Int J Biodiver Sci Manag 1 4-10

Dogra K S, Sood S K, Dobhal P K and Sharma S (2010) Alien plant invasion and their impact on indigenous species diversity at global scale: A review $J$ Ecol Nat Environ 2 $175-186$

Duan K, Yao T and Thompson L G (2004) Low-frequency of southern Asian monsoon variability using a 295-year record from the Dasuopu ice core in the central Himalayas Geophys Res Lett 31 L16206

Ebi K L, Woodruff R, von Hildebrand A and Corvalan C (2007) Climate change-related health impacts in the Hindu KushHimalayas Eco Health 4 264-270

Eriksson M, Jianchu X, Shrestha A B, Vaidya R A, Nepal S and Sandström K (2009) The changing Himalayas: Impact of climate change on water resources and livelihoods in the Greater Himalayas. Kathmandu: ICIMOD

Flanner M G, Zender C S, Hess P G, Mahowald N M, Painter T H, Ramanathan V and Rasch P J (2009) Springtime warming and reduced snow cover from carbonaceous particles Atmos Chem Phys 9 2481-2497

Forrest J L, Wikramanayake E, Shrestha R, Areendran G, Gyeltshen K, Maheshwari A, Mazumdar S, Naidoo R, Thapa G J and Thapa T (2012) Conservation and climate change: Assessing the vulnerability of snow leopard habitat to treeline shift in the Himalaya Biol Conserv 150 129135

Fujita K, Kadota T, Rana B et al. (2001) Shrinkage of glacier AX010 in Shorong region, Nepal Himalayas in the 1990s Bull Glaciol Res 18 51-54

Gautam R, Hsu N C and Lau K M (2010) Pre-monsoon aerosol characterization and radiative effects over the IndoGangetic Plains: Implications for regional climate warming $J$ Geophys Res Atmos 115 1984-2012

Geneletti D and Dawa D (2009) Environmental impact assessment of mountain tourism in developing regions: A study in Ladakh, Indian Himalaya Environ Impact Assess Rev 29 229-242

Gerlitz J Y, Hunzai K and Hoermann B (2012) Mountain poverty in the Hindu-Kush Himalayas Can J Devt Stud 33 250265

Griggs D, Stafford-Smith M, Gaffney O, Rockström J, Öhman M C, Shyamsundar P, Steffen W, Glaser G, Kanie N and Noble I (2013) Sustainable development goals for people and planet Nature 495 305-307

Gilani H, Shrestha H L, Murthy M S R, Phuntso P, Pradhan S, Bajracharya B and Shrestha B (2015) Decadal land cover change dynamics in Bhutan J Environ Manag 148 91-100

GoN/MoFSC (2006) Sacred Himalayan Landscape - Nepal Strategic Plan (2006-2016) broad strategy document. Ministry of Forest and Soil Conservation, Government of Nepal

Guangwei C (2002) Biodiversity in the Eastern Himalayas: conservation through dialogue. Summary reports of the workshops on biodiversity conservation in the Hindu Kush-Himalayan Ecoregion. ICIMOD, Kathmandu, Nepal

Gurung C P (2004) Terai arch landscape: A new paradigm in conservation and sustainable development. In Managing Mountain Protected Areas: Challenges and Responses for the 21st Centaury (Eds. D Harmone and Worboys G L) pp 80-86, Andromeda Editrice, Italy

Hart R, Salick J, Ranjitkar S and Xu J (2014) Herbarium specimens show contrasting phenological responses to Himalayan climate Proc Natl Acad Sci USA 111 10615-10619

Huber U M, Bugmann H K and Reasoner M A (2005) Global Change and Mountain Regions. An Overview of Current Knowledge. Dordrecht, The Netherlands: Springer

ICIMOD (2011) Black carbon in the Hindu Kush Himalayan region. Information Sheet No. 2/11. International Center for Integrated Mountain Development, Kathmandu, Nepal

ICIMOD, MoFSC (2014) An integrated assessment of the effects of natural and human disturbances on a wetland ecosystem: A retrospective from the Koshi Tappu Wildlife Reserve, Nepal. Kathmandu: ICIMOD

ICIMOD, RSPN (2014) An integrated assessment of the effects of natural and human disturbances on a wetland ecosystem: A retrospective from Phobjikha Conservation Area, Bhutan. Kathmandu: ICIMOD 
Immerzeel W W, Van Beek L P and Bierkens M F (2010) Climate change will affect the Asian water towers Science $\mathbf{3 2 8}$ 1382-1385

Inderjit; Evans H, Crocoll C., Bajpai D, Kaur R, Feng YL, Silva C and Callaway R M (2011) Volatile chemicals from leaf litter are associated with invasiveness of a neotropical weed in Asia Ecology 92 316-324

IPCC (2007) The fourth assessment report: Climate change 2007, Synthesis Report. Cambridge, UK: Cambridge University Press

Jha S and Bawa K S (2005) Population growth, human development and deforestation in biodiversity hotspots Conserv Biol 20 906-912

Jodha N S (2000) Globalization and fragile Mountain Environment: Policy challenges and choices Mt Res Dev 20 296-299

Joshi P K, Rawat A, Narula S and Sinha V (2012) Assessing impact of climate change on forest cover type shifts in Western Himalayan Eco-region J Forestry Res 23 75-80

Kabir M, Ghoddousi A, Awan M S and Awan M N (2014)Assessment of human-leopard conflict in Machiara National Park, Azad Jammu and Kashmir, Pakistan Eur J Wildl Res 60 291-296

Kadota T, Seko K, Aoki T, Iwata S and Yamaguchi S (2000) Shrinkage of Khumbu Glacier, east Nepal from 1978 to 1995. IAHS Publication No. 264 235-243

Kala C P (2015) Forest structure and anthropogenic pressures in the Pachmarhi biosphere reserve of India J For Res 1-8

Kandel K, Huettmann F, Suwal M K, Regmi G R, Nijman V, Nekaris K A I and Subedi T R (2015) Rapid multi-nation distribution assessment of a charismatic conservation species using open access ensemble model GIS predictions: Red panda (Ailurus fulgens) in the Hindu-Kush Himalaya region Bio Conserv 181 150-161

Kennedy T A, Shahid N, Katherine M H, Jokannes M H K, David T and Peter R (2002) Biodiversity as a barrier to ecological invasion Nature 417 636-638

Khan S M, Ahmad H, Page S and Harper D M (2012) Anthropogenic influences on the natural ecosystem of the Naran Valley in the western Himalayas PakJ Bot 44 231238

Khuroo A A, Rashid I, Reshi Z, Dar G H and Wafai B A (2007) The alien flora of Kashmir Himalaya Biol Invasions 9269 292

Khuroo AA, Reshi ZA, Malik A H, Weber E, Rashid I and Dar G $\mathrm{H}$ (2012) Alien flora of India: taxonomic composition, invasion status and biogeographic affiliations Biol

\section{Invasions 14 99-113}

Klein G K, Beusen A, Drecht V G and Vos D M (2011) The HYDE 3.1 spatially explicit database of human-induced global land-use change over the past 12,000 years Glob Ecol Biogeogr 20 73-86

Kohli R K, Batish D R, Singh H P and Dogra K S (2006) Status, invasiveness and environmental threats of three tropical American invasive weeds (Parthenium hysterophorus L., Ageratum conyzoides L., Lantana camara L.) in India Biol Invasions 8 1501-1510

Kohli R K, Batish D R, Singh J S, Singh H P, Bhatt J R, Singh S $P$ and Tripathi R S (2012) Plant invasion in India: An overview. In:Invasive alien plants An ecological appraisal for the Indian subcontinent (Eds. Bhatt J R, Singh J S, Singh S P, Tripathi R S and Kohli R K) pp 1-9, CAB International Publishing: Wallingford, Oxon, UK

Kohli R K, Dogra K S, Batish D R and Singh H P (2004) Impact of invasive plants on the structure and composition of natural vegetation of northwestern Indian Himalayas Weed Tech 18 1296-1300

Korte T, Baki A B M, Ofenböck T, Moog O, Sharma S and Hering D (2010) Assessing river ecological quality using benthic macroinvertebrates in the Hindu Kush-Himalayan region Hydrobiologia 651 59-76

Kosaka Y, Saikia B, Mingki T, Tag H, Riba T and Ando K (2010) Roadside distribution patterns of invasive alien plants along an altitudinal gradient in Arunachal Himalaya, India Mt Res Dev 30 252-258

Kunwar R M (2003) Invasive alien plants and Eupatorium: Biodiversity and livelihood Him J Sci 1 129-133

Lam D (2011) How the World Survived the Population Bomb: Lessons From 50 Years of Extraordinary Demographic History Demography 48 1231-1262

Leimgruber P, Kelly D S, Steininger M K, Brunner J, Müller T and Songer M (2005) Forest cover change patterns in Myanmar (Burma) 1990-2000 Environ Conserv 32 356364

Liu S Y, Ding Y J, Li J, Shangguan D H and Zhang Y (2006) Glaciers in response to recent climate warming in Western China Quat Sci 26 762-771

Liu X and Chen B (2000) Climatic warming in the Tibetan Plateau during recent decades Int J Climatol 201 729-1742

Loewen M D, Sharma S, Tomy G, Wang F, Bullock P and Wania F (2005) Persistent organic pollutants and mercury in the Himalaya Aquat Ecosys Health Manage 8223-233

Lutz A F, Immerzeel W W, Shrestha A B and Bierkens M F P (2014) Consistent increase in High Asia's runoff due to 
increasing glacier melt and precipitation Nature Climate Change 4 587-592

MA (Millennium Ecosystem Assessment) (2005) Ecosystems and Human Well-being: Synthesis. Island Press

MacKinnon J (2002) Status of Biodiversity in Asia-ICEM. In: Biodiversity Planning in Asia (Carew-Reid J ed) pp. 4972. IUCN, Gland, Switzerland and Cambridge, UK

Mahat T B S, Griffin D M and Sheperd K R (1987) Human impact of some forest of middle hills of Nepal part 4. A detail study in southeast Sindhu Palchok and northeast Kabre Palanchok Mt Res Dev 7 111-134

Mandal G and Joshi S P (2015) Eco-physiology and habitat invasibility of an invasive, tropical shrub (Lantana camara) in western Himalayan forests of India For Sci Tech 1-15

Maplecroft (2011) Climate change risk atlas 2011. http:// maplecroft.com/search/?q=climate+change+vulnerability +ranking (accessed 20 October 2011)

Marinoni A, Cristofanelli P, Laj P, Duchi R, Calzolari F, Decesari S, Sellegri K, Vuillermoz E, Verza G P, Villani P and Bonasoni P (2010) Aerosol mass and black carbon concentrations, two year-round observations at NCO-P (5079 m, Southern Himalayas) Atmos Chem Phys Discuss $108379-8413$

Marinoni A, Cristofanelli P, Laj P, Duchi R, Putero D, Calzolari F, Landi T C, Vuillermoz E, Maione $\mathrm{M}$ and Bonasoni $\mathrm{P}$ (2013) High ozone and black carbon concentrations during pollution transport in the Himalayas: five years of continuous observations at NCO-P global GAW station $J$ Environ Sci 25 1618-25

Ménégoz M, Krinner G, Balkanski Y, Boucher O, Cozic A, Lim S and Jacobi H W (2014) Snow cover sensitivity to black carbon deposition in the Himalayas: from atmospheric and ice core measurements to regional climate simulations Atmos Chem Phys 14 4237-4249

Menon S, Koch D, Beig G, Sahu S, Fasullo J and Orlikowski D (2010) Black carbon aerosols and the third polar ice cap Atmos Chem Phys 10 4559-4571

Messerli B and Ives J D (1997) Mountains of the World: A Global Priority. New York: Parthenon

Miehe G, Miehe S and Schlütz F (2009) Early human impact in the forest ecotone of southern High Asia (Hindu Kush, Himalaya) Quaternary Research 71 255-265

Mishra S, Maikhuri R K, Kala C P, Rao K S and Saxena K G (2008) Wild leafy vegetables: A study of their subsistence dietetic support to the inhabitants of Nanda Devi Biosphere Reserve, India J Ethnobiol Ethnomed 415 doi:10.1186/1746-4269-4-15
Mittermeier R A, Gils P R, Hoffman M, Pilgrim J, Brooks T, Mittermeier C G, Lamoreaux J and da Fonseca G A B (2004) Hotspots revisited. Earth's biologically richest and most endangered terrestrial ecoregions. CEMEX. USA

Molden D J, Vaidya R A, Shrestha A B, Rasul G and Shrestha M $S$ (2014) Water infrastructure for the Hindu Kush Himalayas Int Water Resour Dev 30 60-77

Motel PC, Choumert J, Minea A and Sterner T (2014) Explorations in the Environment-Development Dilemma Environ Resource Econ 57 479-485

Munsi M, Malaviya S, Oinam G and Joshi P K (2010) A landscape approach for quantifying land-use and land-cover change (1976-2006) in middle Himalaya Reg Environ Change 10 145-155

NCD (2004) Bhutan Biological Conservation Complex: A Landscape Conservation Plan - Way Forward. Nature Conservation Division (NCD) and WWF Bhutan

Nepal S and Shrestha AB (2015) Impact of climate change on the hydrological regime of the Indus, Ganges and Brahmaputra river basins: a review of the literature Int J Water Res Dev DOI: 10.1080/07900627.2015.1030494

Ning W, Ismail M, Joshi S, Qamar F M, Phuntsho K, Weikang Y, Khan B, Shaoliang Y, Kotru R and Sharma E (2014) Understanding the Transboundary Karakoram-Pamir Landscape. ICIMOD, Kathmandu, Nepal

Pandey M R, Neupane R P, Gautam A and Shrestha I B (1989) Domestic smoke pollution and acute respiratory infections in a rural community of the hill region of Nepal Environ Int 15 337-340

Pandit M K, Sodhi N S, Koh L P, Bhaskar A and Brook BW (2007) Unreported yet massive deforestation driving loss of endemic biodiversity in Indian Himalaya Biodivers Conserv 16 153-163

Pant K P, Rasul G, Chettri N, Rai K R and Sharma E (2012) Value of Forest Ecosystem Services: A Quantitative Estimation from Eastern Nepal, Kangchenjunga Landscape. ICIMOD, Kathmandu, Nepal

Partap T and Sthapit B (1998) Managing agrobiodiversity: farmers' changing perspectives and institutional responses in the HKH region. ICIMOD, Kathmandu, Nepal

Poudel R C, Gao L M, Möller M, Baral S R, Uprety Y, Liu J and Li D Z (2013) Yews (Taxus) along the Hindu KushHimalayan region: exploring the ethnopharmacological relevance among communities of Mongol and Caucasian origins J Ethnopharmacology 147 190-203

Purohit A, Maikhuri R K, Rao K S and Nautiyal S (2001) Impact of bark removal on survival of Taxus baccata L. (Himalayan 
yew) in Nanda Devi Biosphere Reserve, Garhwal Himalaya, India Curr Sci 81 586-590

Qian Y, Flanner M G, Leung L R and Wang W (2011) Sensitivity studies on the impacts of Tibetan Plateau snowpack pollution on the Asian hydrological cycle and monsoon climate Atmos Chem Phys 11 1929-48

Quyang H (2009) The Himalayas - water storage under threat. Sustainable Mountain Development 56 3-5

Ramanathan V and Carmichael G (2008) Global and regional climate changes due to black carbon Nature Geoscience $\mathbf{1}$ 221-227

Ramanathan V, Chung C, Kim D, Bettge T, Buja L, Kiehl J T, Washington W M, Fu Q, Sikka D R and Wild M (2005) Atmospheric brown clouds: Impacts on South Asian climate and hydrological cycle Proc Natl Acad Sci USA 102 5326-5333

Ranjitkar S, Luedeling E, Shrestha K K, Guan K and Xu J (2013) Flowering phenology of tree rhododendron along an elevation gradient in two sites in the Eastern Himalayas Int J Biometeorol 57 225-240

Raza G, Mirza S N, Anwar M, Hussain I, Khan S W, Ahmad K and Ahmad N (2015) Population and Distribution of Himalayan Ibex, Capra ibex sibrica, in Hushe Valley, Central Karakoram National Park, Pakistan Pak J Zool 47 1025-1030

Reddy C S, Sreelekshmi S, Jha C S and Dadhwal V K (2013) National assessment of forest fragmentation in India: Landscape indices as measures of the effects of fragmentation and forest cover change Ecol Eng 60453 464

Rikhari H C, Sharma S, Nadeem M and Palni L M S (2000) The effect of disturbance levels, forest types and associations on the regeneration of Taxus baccata: Lessons from the Central Himalaya Curr Sci 79 88-89

Ros-Tonen M A F, Zaal F and Dietz T (2005) Reconciling Conservation Goals and Livelihood Needs: New Forest Management Perspectives in the 21st Century. In: African Forests Between Nature and Livelihood Resources: Interdisciplinary Studies in Conservation and Forest Management (Eds. Ros-Tonen M A F and Dietz T) pp 329 Lewiston NY: The Edwin Mellen Press

Rupa Kumar K, A K Sahai, K Krishna Kumar, S K Patwardhan, P K Mishra, J V Revadekar, K Kamala and G B Pant (2006) High-resolution climate change scenarios for India for the 21st century Curr Sci 90 334-345

Sandhu H and Sandhu S (2015) Poverty, development, and Himalayan ecosystems Ambio 44 297-307
Sapkota S, Aryal A, Baral S R, Hayward M W and Raubenheimer D (2014) Economic Analysis of Electric Fencing for Mitigating Human-wildlife Conflict in Nepal $J$ Resour Ecol 5 237-243

Sarkar S (2010) Climate change and disease risk in the Himalayas Him J Sciences 6 6-8

Saxena K G and Ramakrishnan P S (1984) Growth and patterns of resources allocation in Eupatorium odoratum in secondary successional environment following slash and burn agriculture Weed Res 24 127-34

Schiermeir Q (2010) Glacier estimate on thin ice Geophys Res Lett 463 276-277

Secretariat of the Convention on Biological Diversity (2014) Global Biodiversity Outlook 4. Montréal: CBD Secretariat

Sekar K C, Manikandan R and Srivastava S K (2012) Invasive alien plants of Uttarakhand Himalaya Proc Natl Acad Sci India-Section B 82 375-383

Seko K, Yabuki H, Nakawo M, Sakai A, Kadota T and Yamada Y (1998) Changing surface features of Khumbu glacier, Nepal Himalayas revealed by SPOT images Bull Glaciol Res 16 33-41

Selvan K M, Lyngdoh S, Gopi G V, Habib B and Hussain S A (2014) Population densities, group size and biomass of ungulates in a lowland tropical rainforest forest of the eastern Himalayas Acta Ecol Sin 34 219-224

Semwal R, Nautiyal S, Sen K K, Rana U, Maikhuri R K, Rao K $S$ and Saxena K G (2004) Patterns and ecological implications of agricultural land-use changes: a case study from central Himalaya, India Agric Ecosyst Environ 102 $81-92$

Sen K K, Semwal R L, Rana U, Nautiyal S, Maikhuri R K, Rao K S and Saxena K G (2002) Patterns and implications of land use/cover change: a case study in Pranmati watershed (Garhwal Himalaya, India) Mt Res Dev 22 56-62

Seto K C, Güneralpa B and Hutyra L R (2013) Global forecasts of urban expansion to 2030 and direct impacts on biodiversity and carbon pools Pro Natl Acad Sci USA www.pnas.org/cgi/doi/10.1073/pnas.1211658109

Shah M A, Callaway R M, Shah T, Houseman G R, Pal R W, Xiao S, Luo W and Chen S (2014) Conyza canadensis suppresses plant diversity in its nonnative ranges but not at home: a transcontinental comparison New Phytologist 202 1286-1296

Shakya B, Uddin K, Chettri N, Bajracharya B and Sharma E (2011) Use of geo-spatial tools in the management of potential habitats outside the protected areas in the transboundary Brahmaputra Salween landscape. In 
Contribution of ecosystem restoration to the objectives of the CBD and a healthy planet for all people, Abstracts of posters presented at the 15th meeting of the Subsidiary Body on Scientific, Technical and Technological Advice of the Convention on Biological Diversity, 7-11 November 2011, Montreal, Canada, Technical Series No. 62, pp 98100. Montreal, Canada: Secretariat of the Convention on Biological Diversity

Sharma B, Rasul G and Chettri N (2015) The Economic Value of Wetland Ecosystem Services: Evidence from Koshi Tappu Wildlife Reserve, Nepal Ecosyst Serv 12 84-93

Sharma E and Chettri N (2003) Sustainable Biodiversity Management Practices in the Hindu-Kush Himalayas. In Proceedings of Norway/UN Conference on Technology Transfer and Capacity Building (Eds. Sandlund O T and Schei P J) pp 82-88. Norwegian Directorate of Nature Management and Norwegian Institute for Nature Research, Trondheim, Norway

Sharma E and Chettri N (2005) ICIMOD's Transboundary Biodiversity Management Initiative in the Hindu KushHimalayas Mt Res Dev 25 280-283

Sharma E, Chettri N and Oli K P (2010) Mountain biodiversity conservation and management: a paradigm shift in policies and practices in the Hindu Kush-Himalayas Ecol Res $\mathbf{2 5}$ 905-923

Sharma E, Chettri N, Gurung J and Shakya B (2007) Landscape approach in biodiversity conservation: A regional cooperation framework for implementation of the Convention on Biological Diversity in Kangchenjunga Landscape. ICIMOD, Kathmandu, Nepal

Sharma E, Chettri N and Gyamtsho P (2006) Advances in community based natural resources management in the Hindu Kush-Himalayan Region. In: Capitalisation and Sharing of Experiences on the Interaction between Forest Policies and Land Use Pattern in Asia, Volume 2 (Eds. Gymtsho P, Singh B K and Rasul G) pp 9-23. ICIMOD, Kathmandu, Nepal

Sharma E, Chettri N and Oli K P (2010) Mountain biodiversity conservation and management: a paradigm shift in policies and practices in the Hindu Kush-Himalayas Ecol Res $\mathbf{2 5}$ 905-923

Sharma R (2012) Impacts on human health of climate and land use change in the Hindu Kush-Himalayan Region Mt Res Dev 32 480-486

Shea J M, Immerzeel W W, Wagnon P, Vincent C and Bajracharya $\mathrm{S}$ (2015) Modelling glacier change in the Everest region, Nepal Himalaya The Cryosphere 9 1105-1128
Sherpa M, Wangchuk S and Wikramanayake E D (2004) Creating biological corridors for conservation and development: A case study from Bhutan. In: Managing Mountain Protected Areas: Challenges and Responses for the 21st Century (Eds. Harmone D and Worboys G L) pp 128-134. Andromeda Editrice, Italy

Sherpa L N, Peniston B, Lama W and Richard C (2003) Hands around Everest: transboundary cooperation for conservation and sustainable livelihoods. International Centre for Integrated Mountain Development (ICIMOD), Kathmandu, Nepal

Sherpa M and Norbu U P (1999) Linking protected areas for ecosystem conservation: a case study from Bhutan Parks $935-45$

Shi Y (2001) Ke yujian de Qingzang Gaoyuan huanjing da bianhua (zaiyao) Yanhu Yanjiu 9 2-3

Shrestha A B and Aryal R (2011) Climate change in Nepal and its impact on Himalayan glaciers Regl Environ Change 11 6577

Shrestha A B and Devkota L P (2010) Climate change in the Eastern Himalayas: Observed trends and model projections; Climate change impact and vulnerability in the Eastern Himalayas - Technical report 1. ICIMOD, Kathmandu, Nepal

Shrestha A B, Wake C P, Dibb J E and Mayewski P A (2000) Precipitation fluctuations in the Nepal Himalaya and its vicinity and relationship with some large scale climatological parameters Int J Climatol 20 317-327

Shrestha A B, Wake C P, Mayewski P A and Dibb J E (1999) Maximum temperature trends in the Himalaya and its vicinity: An analysis based on temperature records from Nepal for the period 1971-94 J Climate 12 2775-2786

Shrestha U B and Bawa K S (2014) Impact of Climate Change on Potential Distribution of Chinese Caterpillar Fungus (Ophiocordyceps sinensis) in Nepal Himalaya. PLoS ONE9(9): e106405. doi:10.1371/journal.pone.0106405

Shrestha P, Barros A P and Khlystov A (2010) Chemical composition and aerosol size distribution of the middle mountain range in the Nepal Himalayas during the 2009 pre-monsoon season Atmos Chem Phys 10 11605-21

Shrestha U B, Gautam S and Bawa K S (2012) Widespread climate change in the Himalayas and associated changes in local ecosystems PLoS One 7 e36741

Singh J S (2006) Sustainable development of the Indian Himalayan region: Linking ecological and economic concerns $\mathrm{Curr}$ Sci $90784-788$

Singh S P, Bassignana-Khadka I, Karky B S and Sharma E (2011) 
Climate Change in the Hindu Kush-Himalayas: The State of Current Knowledge. Kathmandu: ICIMOD

Singh S P, Negi G C S, Pant M C and Singh J S (1992) Economic considerations in the Central Himalayan agroecosystems. In The Price of Forest (Ed. Agrawal A) pp 291-296 Centre for Science and Environment, New Delhi

Squires D (2014) Biodiversity Conservation in Asia Asia Pacific Policy Stud 1 144-159

Srivastava A K, Soni VK, Singh S, Kanawade V P, Singh N, Tiwari S and Attri S D (2014) An early South Asian dust storm during March 2012 and its impacts on Indian Himalayan foothills: A case study Science Total Environ 493 526-534

Sundriyal R C and Sharma E (1996) Anthropogenic pressure on tree structure and biomass in the temperate forest on Mamlay Watershed in Sikkim For Ecol Manage 81 113134

Tan L, Cai Y, Yi L, An Z and Ai L (2007) Precipitation variations of Longxi, northeast margin of Tibetan plateau since AD 960 and its relationship with solar activity Clim Past 3 1037-1061

Tiwari S, Adhikari B, Siwakoti M and Subedi K (2005) An inventory assessment of invasive alien plant species of Nepal, IUCN-The World Conservation Union, Nepal. Viii+ pp. 116

Tripathi R S, Khan M L and Yadav A S (2012a) Biology of Mikania micrantha H.B.K: A review. In:Invasive alien plants: An ecological appraisal for the Indian subcontinent (Eds. Bhatt J R, Singh J S, Singh S P, Tripathi R S and Kohli R K) pp 99-107 CAB International Publishing: Wallingford, Oxon, UK

Tripathi R S, Yadav A S and Kushwaha S P S (2012b) Biology of Chromolaena odorata and Ageratina adenophora. In Invasive alien plants: An ecological appraisal for the Indian subcontinent (Eds. Bhatt J R, Singh J S, Singh S P, Tripathi R S and Kohli R K) pp 43 CAB International Publishing: Wallingford, Oxon, UK

Tse-ring K (2003) 'Constructing future climate scenarios of Bhutan'. In Project report on climate change vulnerability and adaptation study for rice production in Bhutan; for Project: Climate change studies in Bhutan, Activity No www094505-But.2.Royal Government of Bhutan, Ministry of Agriculture, Thimphu, Bhutan

Tse-ring K, Sharma E, Chettri N and Shrestha A (2010) Climate change vulnerability of mountain ecosystems in the Eastern Himalayas; Climate change impact an vulnerability in the Eastern Himalayas - Synthesis report. Kathmandu:

\section{ICIMOD}

Tulachan P (2001) Mountain agriculture in the Hindu KushHimalaya Mt Res Dev 21 260-267

Uddin K, Chaudhary S, Chettri N, Kotru R, Murthy M S R, Chaudhary R P, Ning W, Shrestha S M and Gautam S G (2015) The changing land cover and fragmenting forest on the Roof of the World: A case study in Nepal's Kailash Sacred Landscape Landsc Urban Plan 141 1-10

UNEP and GAW (2011) Integrated Assessment of Black Carbon and Tropospheric Ozone UNEP Nairobi

UNFPA (2001) Foot Prints and Milestones: Population and Environmental Change. United Nations Population Fund, New York

Vedwan N (2006) Culture, climate and the environment: Local knowledge and perception of climate change among apple growers in northwestern India J Ecol Anthropology $104-$ 18

Viviroli D, Durr H H, Messerli B, Meybeck M and Weingartner (2007) Mountains of the world, water towers for humanity: Typology, mapping, and global significance Water Resour Res 43 W07447, doi:10.1029/2006 WR005653.

Wakeel A, Rao K S, Maikhuri R K and Saxena K G (2005) Forest management and land use/cover changes in a typical micro watershed in the mid elevation zone of Central Himalaya, India For Ecol Manage 213 229-242

Wang Y, Hou S, Hong S, Hur S D and Liu Y (2008) Glacier Extent and Volume Change (1966-2000) on the Su-lo Mountain in Northeastern Tibetan Plateau, China J Mt Sci 5 299-309

Watson J E M, Dudley N, Segan D B and Hockings M (2014) The performance and potential of protected areas Nature 515 67-73

Wikramanayake E D, Dinerstein E, Robinson J G., Karanth U, Rabnowitz A, Olson D, Mathew T, Hedae P, Conner M, Hemley G and Bolze D (1998) An ecology-based method for defining priorities for large mammal conservation: the tiger as case study Conserv Biol 12 865-878

Xu B, Cai J, Hansen J, Yao T Joswia D R Wang N, Wu G, Wang M,http://www.pnas.org/content/106/52/22114.full - aff1 Zhao, Yang W, Liu X and He J (2009) Black soot and the survival of Tibetan glaciers P Natl Acad Sci USA 10622114 8

Xu J, Grumbine E R, Shrestha A B, Eriksson M, Yang X, Wang Y and Wilkes A (2009) The melting Himalayas: Cascading effects of climate change on water, biodiversity, and livelihoods Conserv Biol 23 520-530

Yao T, Duan K, Xu B, Wang N, Guo X and Yang X (2008) 
Precipitation record since AD 1600 from ice cores on the central Tibetan Plateau Clim Past 4 175-180

Yao T, Pu J, Lu A, Wang Y and Yu W (2007) Recent glacial retreat and its impact on hydrological processes on the Tibetan Plateau, China, and surrounding regions Arctic, Antarctic, and Alpine Research $39642-650$

Yonzon P B (1989) Ecology and conservation of the red panda in the Nepal-Himalayas. Ph D Thesis, University of Maine, Orono, Maine

Yin Y Y (2006) Vulnerability and adaptation to climate variability and change in western China, AS 25 Project Final Report to AIACC, International START Secretariat Washington DC, USA

Yunling H and Yiping Z (2005) Climate change from 1960 to 2000 in the Lancang river valley, China Mt Res Dev $2534-$ 348

Zedan H (2005) The role of the convention on biological diversity and its protocol on biosafety in fostering the conservation and sustainable use of the world's biological wealth for socio-economic and sustainable development $J$ Ind Microbiol Biotechnol 32 496-501

Zhao L, Ping C L, Yang D, Cheng G, Ding Y and Liu S (2004) Changes of climate and seasonally frozen ground over the past 30 years in Qinghai-Xizang (Tibetan) Plateau, China Glob Planet Change 43 19-31

Zomer R J, Ustin S L and Carpenter CC (2001) Land cover change along tropical and subtropical riparian corridors within the Makalu Barun National Park and Conservation Area, Nepal Mt Res Dev 21 175-183

Zomer R and Oli KP (2011) Kailash sacred landscape conservation initiative - Feasibility assessment report ICIMOD, Kathmandu, Nepal

Zomer R J, Trabucco A, Metzger M J, Wang M, Oli K P and Xu J (2014) Projected climate change impacts on spatial distribution of bioclimatic zones and ecoregions within the Kailash Sacred Landscape of China, India, Nepal Clim Change 125 445-460. 
